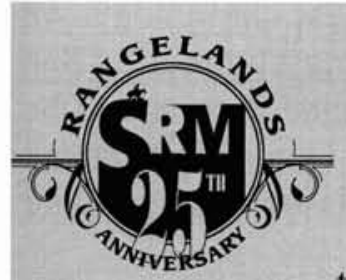

\title{
A Range Management Review
}

\section{By David Bradford, Justin McConkey and Floyd Reed}

This year marks the $25^{\text {th }}$ anniversary of Rangelands. We also need to remember that this past 25 years also represents about half the time that the science of range management has been in existence - the American Society of Range Management being formed in 1948. In essence, the rangelands of the United States have been managed by scientific principles for at least 50 years.

Yet there is an increasing clamor that our public rangelands are still in unsatisfactory condition-that livestock grazing has destroyed the public rangelands and the only way to save them is to remove livestock from those lands. These statements beg the question - has range management failed?

This is a formidable question for range management professionals to ponder. Yet we need to confront the issue. Has the science, efforts and funding of the last 50 years been mistaken, misdirected and misspent? What have we done for the past 25 or even 50 years? Has the profession of range management succeeded or failed? We would like to address these questions from the perspective of a book that was published in 1976. A book titled Public Grazing Lands: Use and Misuse by Industry and Government.

The 1970's are generally considered to be the decade of the flowering of the American environmental movement. Nearly 50 environmental laws were passed by the U.S. Congress in the 1970'sincluding the Endangered Species Act, the National Environmental Policy Act, the National Forest Management Act, the Forest and Rangeland Renewable Resources Planning Act, the Public Rangelands Improvement Act, etc.

In 1976 William Voigt Jr. published Public Grazing Lands: Use and Misuse by Industry and Government. Voigt was a long-time conservationist and former national executive director of the Izaac Walton League of America. In his book, Voigt described the unsatisfactory conditions of the public grazing lands of the United States. Like many controversial issues the story is a complex one. However, the book chronicles the development of livestock grazing in the western United States and reviews the development of range management on the public rangelands of the West. Voigt examines the establishment of grazing management on the National Forests and the remaining public rangelands and the conflicts that developed in the late 1940 's and early 1950's on those rangelands between ranchers and public land managers.

The primary element of the narrative was an effort by ranchers to privatize parts of the national forests and public lands. Voigt's final assessment of the agencies land management efforts was that the Forest Service was entangled in a complicated system of range management that entailed large expenditures of appropriated funds for rehabilitative measures, with few grazing concessions by grazing permittees. While the BLM also suffered from this they also lacked the enforcement authority to adequately manage the public rangelands due to shortcomings in the Taylor Grazing Act. Voigt concluded his book with "Until the one (BLM) is given new power and exercises it, and the other (Forest Service) changes its practices, it appears that western public ranges will continue to suffer the ills of 'too early use, too heavy use and too long use'."

Have conditions changed over the past 25 years? Do the Forest Service and BLM manage the public rangelands any differently today than in 1976 or do our public rangelands continue to suffer the ills of too early use, too heavy use and too long use?

\section{What Has Range Management Accomplished?}

We need to look at the past in order to evaluate the conditions we have today. Many authors have made such an analysis, including Voigt in Public Grazing Lands: Use and Misuse by Industry and Government. Recently Dr. Thad Box in a column titled "Ministers to the Land" in the December 2001 


\section{Grazing Use on the National Forests and Grand Mesa, Uncompahgre and Gunnison National Forests}

\begin{tabular}{|c|c|c|c|}
\hline \multicolumn{2}{|c|}{$\begin{array}{l}\text { Animal Unit Months } \\
\text { (AUMs) of Grazing Use on } \\
\text { National Forests in six } \\
\text { Western Regions: }\end{array}$} & \multicolumn{2}{|c|}{$\begin{array}{l}\text { AUMs of } \\
\text { of Grazing Use } \\
\text { the GMUG NF: }\end{array}$} \\
\hline $1908 *$ & $14,000,000$ & 1917 & 680,508 \\
\hline $1 \overline{918 *}$ & $20,400,000$ & 1918 & 804,760 \\
\hline $1928^{*}$ & $12,600,000$ & 1925 & 694,633 \\
\hline $1938^{*}$ & $11,100,000$ & 1935 & 612,545 \\
\hline $1948^{*}$ & $7,982,000$ & 1945 & 391,461 \\
\hline $1958 * *$ & $8,376,000$ & 1955 & 270,713 \\
\hline $1968^{*}$ & $7,617,000$ & 1965 & 249,333 \\
\hline $1970 *$ & $7,408,000$ & 1970 & 258,751 \\
\hline $1980^{* * *}$ & $8,031,266$ & 1980 & 334,489 \\
\hline $1992 * * *$ & $9,167,927$ & 1990 & 319,152 \\
\hline $2001 * * *$ & $6,023,454$ & 2001 & 272,812 \\
\hline
\end{tabular}

*Figures from Public Grazing Lands: Use and Misuse by Industry and Government. Original source was Forest Service, Washington, D.C.

**This increase is due to the addition of the LU lands that were transferred from the Soil Conservation Service to the National Forest System in 1954. Today these are the National Grasslands.

***Figures from Grazing Statistical Summary, USDA Forest Service. Figures in 1980 represent a change in how an AUM is calculated. The definition of an animal unit month for the earliest figures is the forage required to sustain one animal unit for one month; an animal unit means a cow plus un-weaned calf or five ewes with their suckling lambs. In the 1980's the Forest Service modified this definition to-the amount of feed or forage required by an animal unit for one month. An animal unit is considered to be one mature ( 1,000 pound) cow or the equivalent based upon average forage consumption of 26 pounds dry matter per day. For cow/calf pairs the animal unit equivalent is currently considered to be 1.32.

Obviously, there has been a significant reduction in grazing use on the national forests. Adjusting the 2001 figures for the change in definition for calculating an AUM, the use in 2001 is approximately $30 \%$ of the use that was authorized in 1918; and $51 \%$ of the use that was authorized in 1948. The permitted grazing use in 2001 represents a $70 \%$ reduction of the permitted use in 1918. These figures portray a dramatic reduction in livestock use. issue of Rangelands wrote a similar chronology. We have used both in the following summary. (See sidebar Grazing Use on the National Forests and the Grand Mesa, Uncompahgre and Gunnison National Forests (GMUGNF) for details on changes and trends on this use.)

During the early settlement of the West, livestock grazing was uncontrolled and unregulated. The earliest efforts to manage livestock grazing on public lands occurred on the Forest Reserves/National Forests in the late 1890's-early 1900's. The Forest Service developed a permit system that attempted to limit livestock grazing and charged a fee for this use on these forest rangelands.

From 1910-1920 the first systematic approaches to range management were developed by James Jardin, Arthur Sampson and Frederick Clements. However, during World War I the United States encouraged livestock production on the public lands to aid in the war effort- (see Sidebar Grazing Use on the National Forests and Grand Mesa, Uncompahgre and Gunnison National Forests.) This heavy stocking is reported to have had a profound impact on the ranges on the National Forests, while grazing on the remainder of the rangelands of the public domain (today's public lands managed by the Bureau of Land Management) continued to be unmanaged.

In the 1930's the Taylor Grazing Act was passed and the first regulation of domestic livestock grazing on public domain rangelands began. Most range management in this time involved limiting the numbers of livestock and shortening the season of use. These efforts resulted in the so-called range wars of the 1940's and 1950's. The result of these efforts was a reduction in use - grazing use on the National Forests declined 45\% from 1918 to 1938 .

In the 1940's the science of range management became formalized with the creation of the American Society for Range Management and the creation of range science departments in various land grant colleges in the West. In Colorado, the Department of Grazing and Range Management at Colorado A\&M (today's Colorado State University) was created in 1947. In the 1950's the profession of range management expanded and various techniques and grazing strategies were developed. The first systematic range analysis was conducted on the national forests. 


\section{Big Blue Creek on Big Blue allotment in 1948 and 2001}

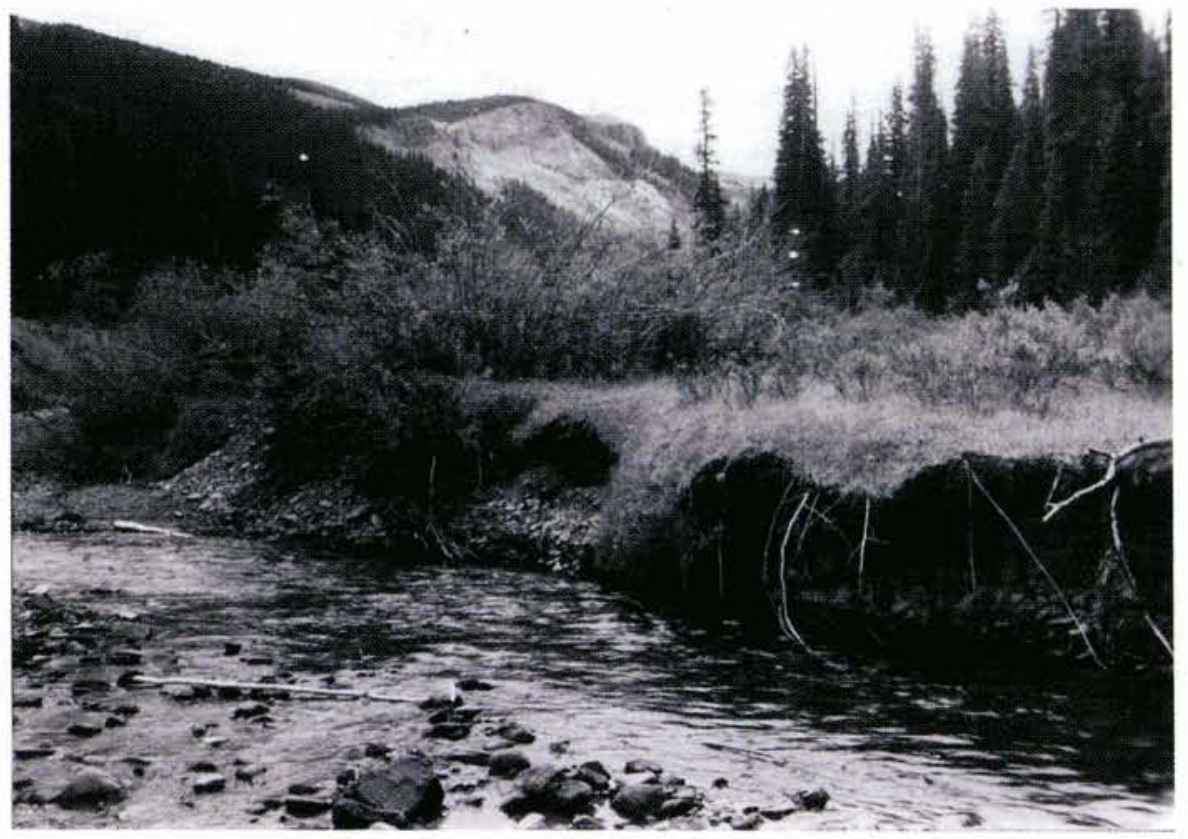

Photo by Arthur Cramer, 8-16-1948 - Denver Public Library, Western History Collection

Allotment was grazed season-long by 450 cow/calf pairs from July 1 to October 15 . This area was grazed by approximately 100 pairs for the season. Cramer noted that stream bank was undercut by excessive run-off. Precipitation for the year was "average."

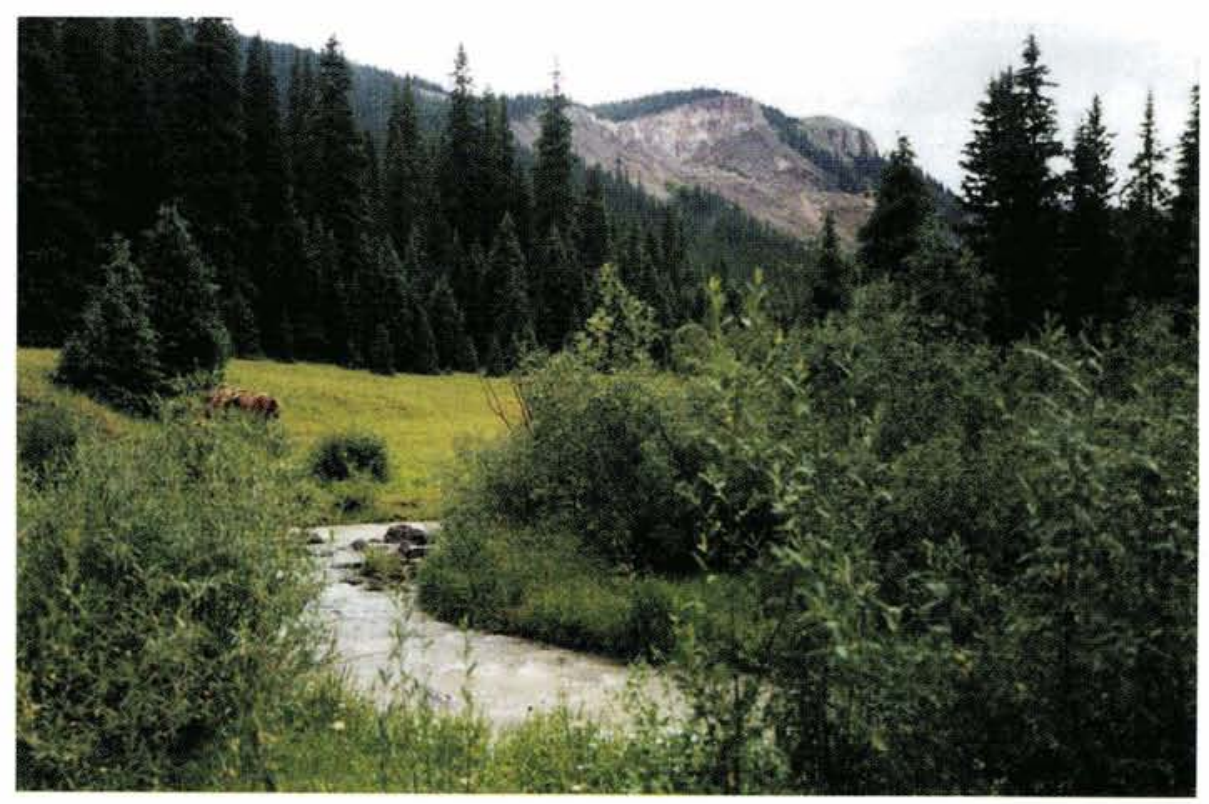

Photo by David Bradford, 8-02-2001

U.S. Forest Service

The allotment was converted to a 4-pasture rest rotation system in 1966 and grazed by 175 cow/calf pairs from 7/16-10/15. This pasture was rested every $4^{\text {th }}$ year. Livestock last grazed the allotment in 1996. Precipitation for the year was $88 \%$ of average. 
From the 1960's to 1970's grazing entered the stage of more intensive range management. Grazing rotations combined with extensive structural and non-structural range improvements were developed and implemented. These efforts generally focused on producing increased amounts of forage. However, the emphasis was often on expensive land treatments such as range seeding and mechanical or herbicidal treatments of undesirable vegetation, such as oak-brush or sagebrush. These efforts often produced dramatic responses of increased forage but if the management of the livestock was ignored or minimally addressed the results were often temporary or unsatisfactory.

By the 1980's the emphasis moved towards "grazing systems." These systems were essentially grazing schedules that focused on moving or rotating livestock into a system of pastures to limit the amount of time that an area was grazed by livestock. The systems generally had fixed schedules. These systems usually failed to consider plant physiology, plant species composition and plant-animal inter-relationships. While the overall system generally included a variety of range improvements, including fencing, water developments and non-structural improvements, especially prescribed burning, the emphasis was mostly on the grazing schedule.

In the 1990's the emphasis has been to incorporate ecological processes into range management. There has been increased emphasis on riparian areas, wildlife-including threatened, endangered, and sensitive species and recreation uses. In the Forest Service this emphasis was called "Change on the Range." This switch was later applied to all Forest Service programs and given the title "Ecosystem Management." As applied to range management this has resulted in an increasingly complicated process of planning that incorporates the time of grazing intensity of grazing and frequency of grazing with plant physiology, plant responses to grazing and livestock nutritional requirements. On the GMUG NF this approach has allowed us to use domestic livestock grazing as a tool to manage vegetation for a variety of objectives, including species composition and vegetation structure.

\section{Have Conditions Improved?}

Have these efforts resulted in improvement or even changes on the ground? Since the late 1990's we have been re-evaluating conditions on the Grand Mesa, Uncompahgre and Gunnison National Forests. We have included past monitoring data points and photographs taken in range inspections over the past 50 to 100 plus years as part of these evaluations. These efforts include photographs and inspections referred to by Voigt in Public Grazing Lands: Use and Misuse by Industry and Government. The Forest has evaluated literally thousands of sites, including several hundred of the historic photo-points,

We have included several examples of these photographs in this article. These photographs are valuable for several reasons. First, they show that improperly managed livestock grazing can and does cause significant environmental damage. Second, they show that properly managed livestock grazing can maintain and in fact provide for recovery of damaged areas.

These photographs and our evaluations indicate recovery of all sites that were identified as depleted, damaged or unsatisfactory. All the sites we have looked at are ecologically functioning and in satisfactory condition. The comparison photographs provide convincing examples of that improvement. It is important to note that the improvement at these sites took place with the continuation of grazing. The improvement being due to 1) adjustments in stocking and 2) changes in management. This is not to say that conditions are perfect or even what they should be in all areas. But they all show improvement and generally dramatic improvement.

Wildlife is another significant component of our Western rangelands. While there are many species of wildlife there is often little information on what those populations were prior to settlement or what they currently are for that matter. However, it is widely accepted that following early settlement, the populations of big game-deer, elk etc. were severely depleted due to over-hunting.

In the 1920's the big game populations for the entire state of Colorado were estimated to be 23,859 deer and 5,384 elk. In the year 2000, those populations were estimated to be 516,000 deer and $230,000 \mathrm{elk}$. The increase in deer numbers 


\section{Bear Trap Park on Dyer allotment in 1948 and 2001}

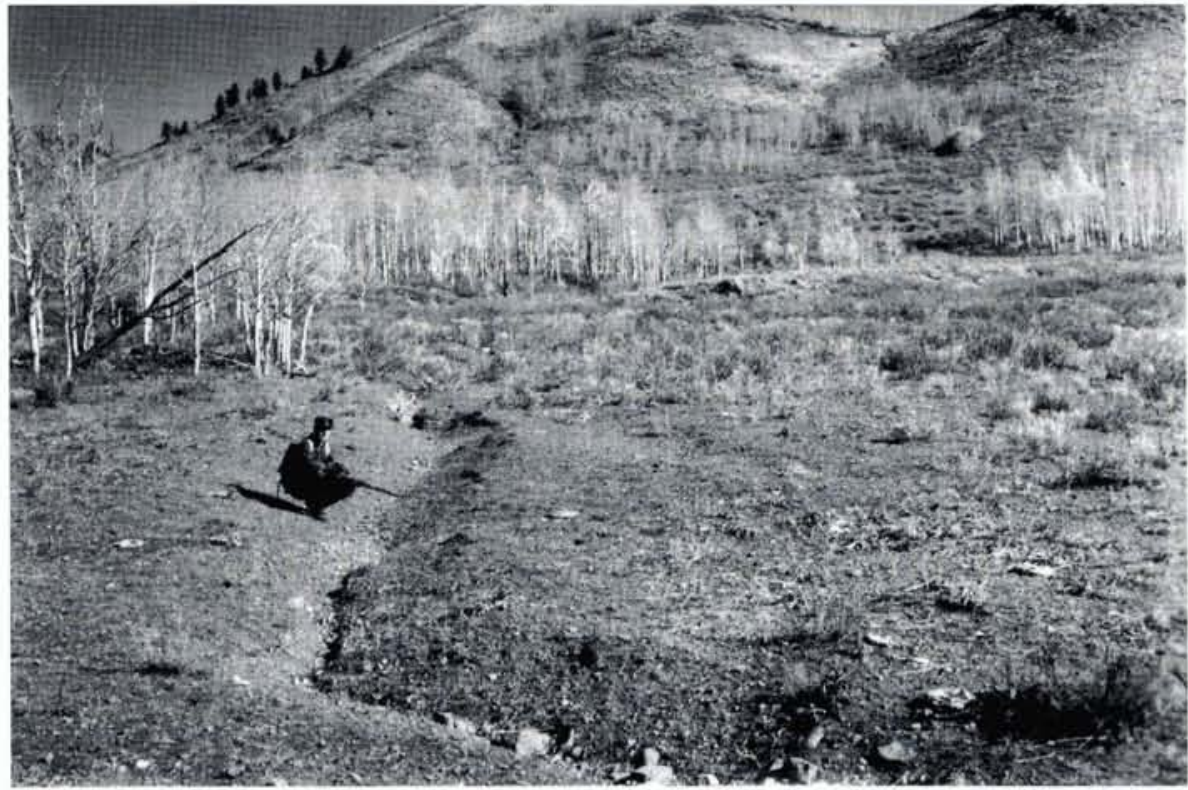

Photo by Arthur Cramer, 10-15-1948 - Denver Public Library, Western History Collection

Allotment was grazed season-long by 1,048 cow/calf pairs from May 15 to October 15, 1948. Note 2-foot deep, raw gully, bare ground and lack of vegetative cover. Shrubs are primarily snowberry. Precipitation for the year was "average."

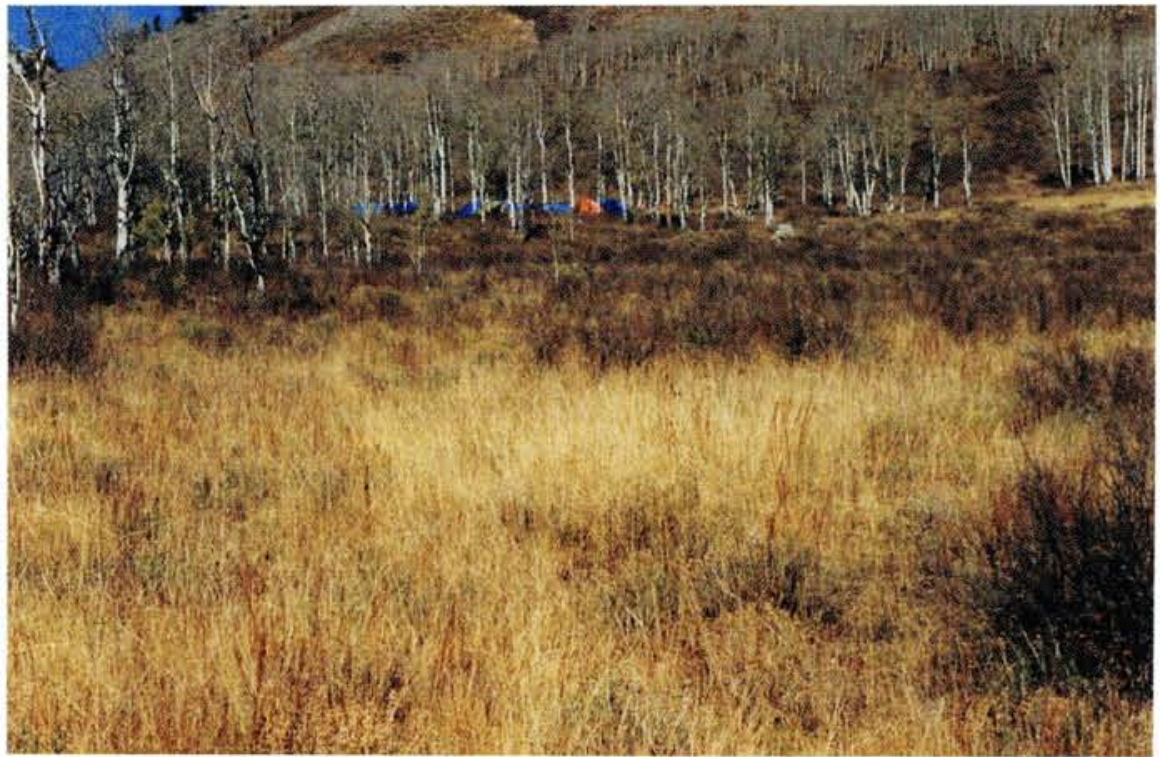

Photo by David Bradford, 10-18-2001

U.S. Forest Service

Dyer allotment now managed under a deferred/rest rotation system. This pasture is rested every other year-it was rested in 2001. In the years this pasture is grazed, 425 cow/calf pairs use it for 27 days. Precipitation for the year was $88 \%$ of average. 
statewide from 1920 to 2000 exceeds $2,000 \%$; the increase in deer numbers on the GMUG NF from 1924 to 2000 represents a $1,145 \%$ increase. The change in elk numbers is even more dramaticstatewide from 1920 to 2000 it is over $4,000 \%$ while the increase on the GMUG NF is over $3,000 \%$. (See Sidebar Colorado Deer and Elk Populations for more details.) These increased populations have had impacts on our rangelands - see Photograph on elk grazing on Robinson Flats. Managing these impacts are some of the challenges that we continue to face as rangeland managers.

At the same time these other changes have occurred there has been significant changes in our human populations. Since 1970 the world population has increased $64 \%$, the United States population has increased $38 \%$, the population in Colorado has increased $94 \%$ and the population in Delta County has increased $77 \%$. (See sidebar on Human Populations for details.) These increased human populations have translated into increased pressures

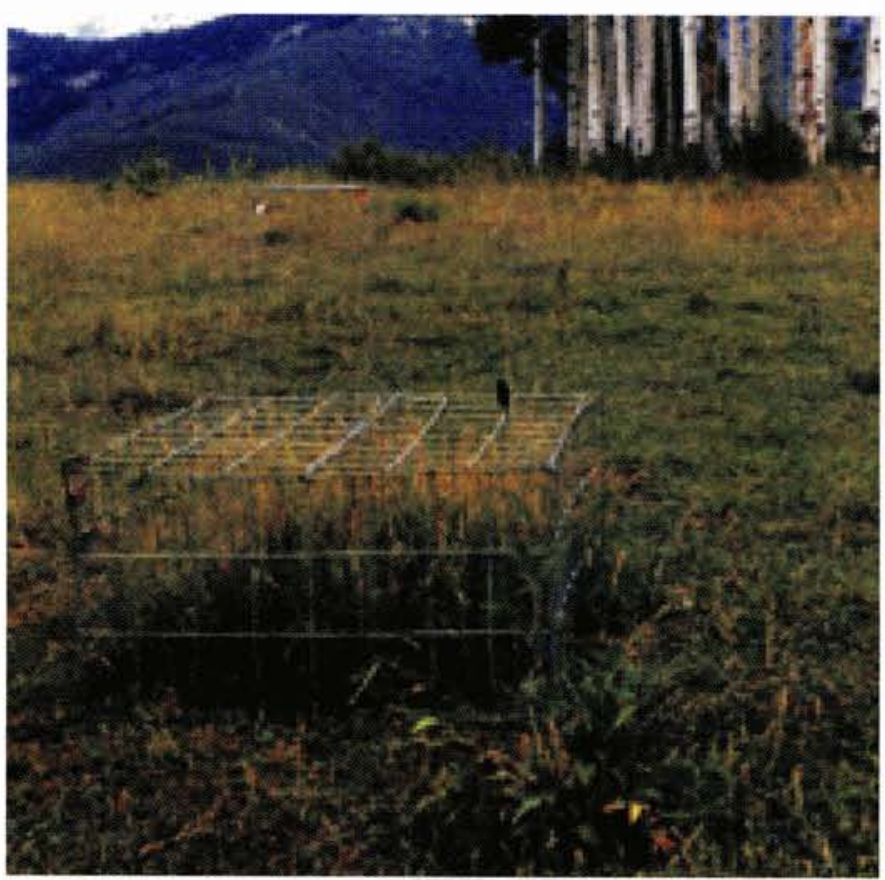

This allotment is grazed by 1,066 cow/calf pairs on a holistic management based grazing strategy. The allotment has 30 pastures that are grazed from 3 to 18 days. This area, a 5 acre park known as Robinson Flat was broadcast seeded to smooth brome, orchardgass and timothy in the 1960's. Grazing use by elk and cattle was measured in 1996-1998. Elk use measured from $39-76 \%$ in those three years. The use shown above measured $76 \%$. Cattle did not move into this pasture until 8-31. Obviously this amount of grazing by elk is having an effect on conditions on this site.

\begin{tabular}{|l|c|c|c|r|}
\hline \multicolumn{5}{|c|}{ Colorado Deer \& Elk Populations } \\
\hline & \multicolumn{2}{|c|}{ State-wide } & \multicolumn{2}{c|}{ GMUG NF** } \\
\hline Year: & Deer & Elk & Deer & Elk \\
\hline 1920 & 23,859 & 5,384 & & \\
\hline 1924 & & & 5,320 & 1,122 \\
\hline 1930 & 45,000 & 17,000 & & \\
\hline 1940 & 171,030 & 23,155 & & \\
\hline 1950 & & & 84,000 & 8,000 \\
\hline 1960 & & & 62,000 & 11,000 \\
\hline 1970 & & & 79,000 & 10,800 \\
\hline 1980 & & & 89,981 & 38,707 \\
\hline 1990 & 700,000 & 180,000 & 77,781 & 35,536 \\
\hline 2000 & 516,000 & 230,000 & 66,252 & 38,887 \\
\hline
\end{tabular}

*Source-Colorado Division of Wildlife.

**Source-Grand Mesa, Uncompahgre and Gunnison National Forests Annual Range and Wildlife Reports.

These figures show significant and dramatic increases in wildlife numbers. The increase in deer numbers statewide from 1920 to 2000 exceeds $2,000 \%$; the increase in deer numbers on the GMUG NF from 1924 to 2000 represents a $1,145 \%$ increase. The change in elk numbers is even more dramatic-statewide from 1920 to 2000 it is over $4,000 \%$ while the increase on the GMUG NF is over $3,000 \%$.

Wildlife populations have generally been controlled by adjusting hunting pressure. The increases in deer and elk numbers from 1920 to 1940 occured by severely restricting hunting. The resulting increases put so much pressure on the winter ranges that the Colorado Division of Wildlife initiated a supplemental feeding program. However this was expensive and generally exacerbate the problem. Hunting seasons were liberalized and wildlife pressure on the winter ranges decreased.

Elk numbers have continued to show a constant increase while deer numbers have declined in the last ten years. The cause(s) of this decline have been studied with a number of factors being identified-1) Deterioration and loss of habitat (Primarily increases in woody vegetation such as pinyon-juniper woodlands), 2) competition with elk, 3) predation (coyotes, mountain lions and black bear), 4) disease and 5) hunting. The exact cause remains speculative and the issue continues to be controversial. In all likelihood all five factors probably contribute in varying degrees.

The effect of deer and elk populations on the land continues to be discussed and debated. Wildlife can and do have significant impacts on land conditions. Many western states, including Colorado, have wildlife damage laws to compensate landowners for damage to private property by wildlife. In the 1980's elk began to winter in the North Fork Valley and started causing severe damage to the fruit orchards in the valley. As a result the CDOW paid to fence the orchards with game fencing to keep the elk out. On the GMUG NF we have observed and documented significant effects of elk grazing on rangelands. While generally very localizedthese areas vary from 1 to 10 acres in size; the grazing by elk has significant effect on the condition of these sites. 


\section{Owens Creek allotment 1949 and 2000}

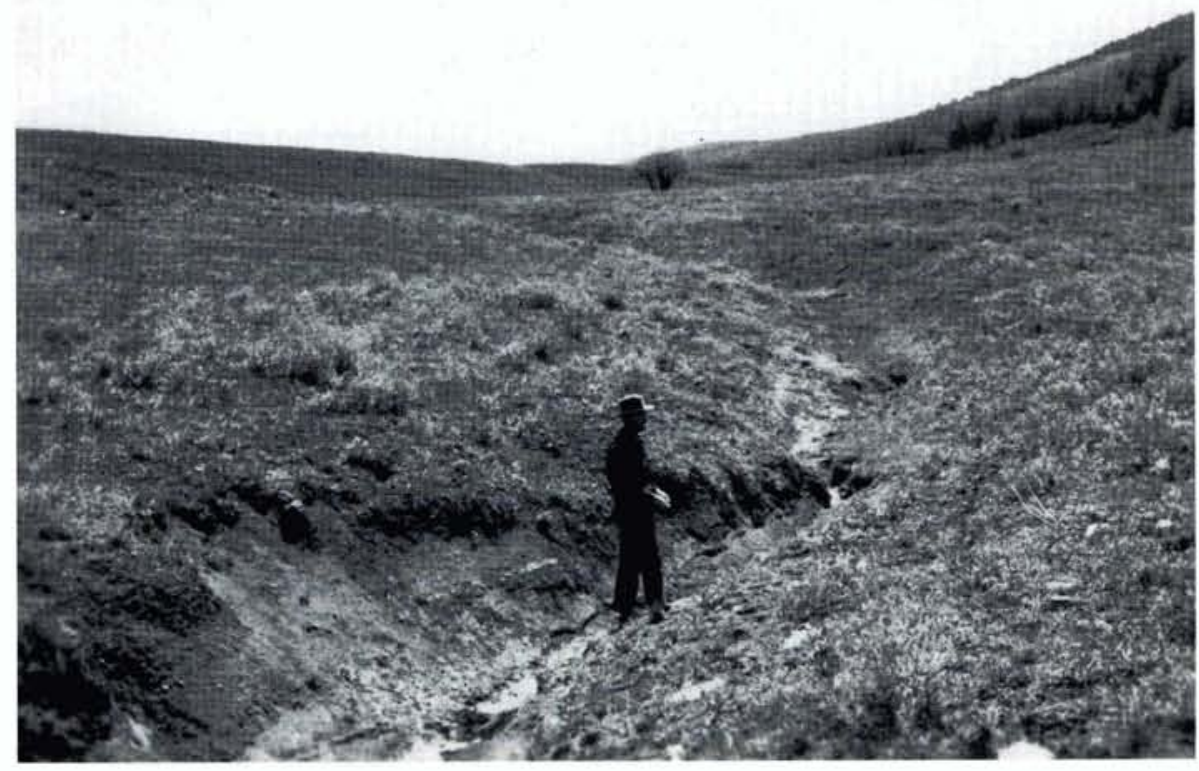

Photo by Arthur Cramer, 9-27-1949 - Denver Public Library, Western History Collection

Slope above Owens Creek on Grand Valley RD. Photograph taken to show gully formation. Allotment was grazed by approximately 3,546 head of cow/calf pairs from June 16 through late October 15 . Precipitation for the year was $110 \%$ of "average."

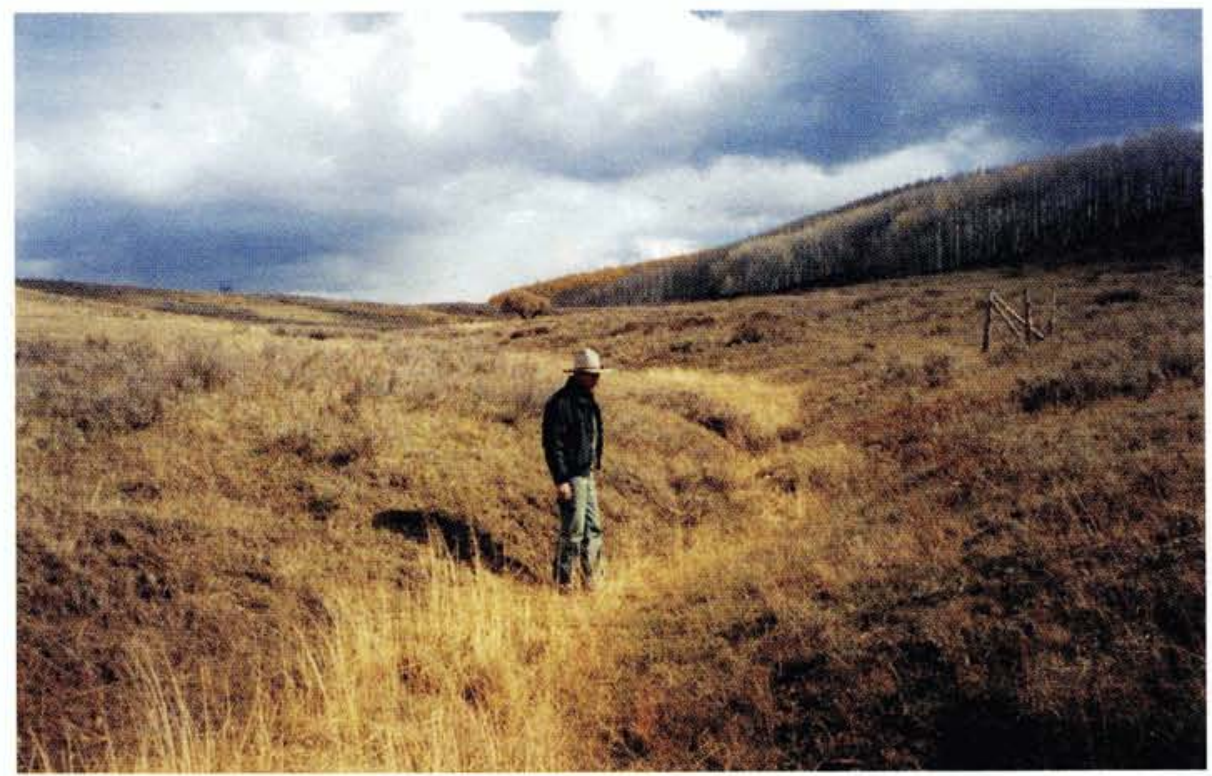

Photo by Bob Mosher, 10-13-2000

U.S. Forest Service

View of same site in 2000. The allotment is currently managed using a deferred-rotation grazing strategy. This area was grazed by 2,188 cow/calf pairs from about September 25 to October 5, 2000. Precipitation for the year was $80 \%$ of "average." 


\section{Horse Fly allotment 1950 and 2001}

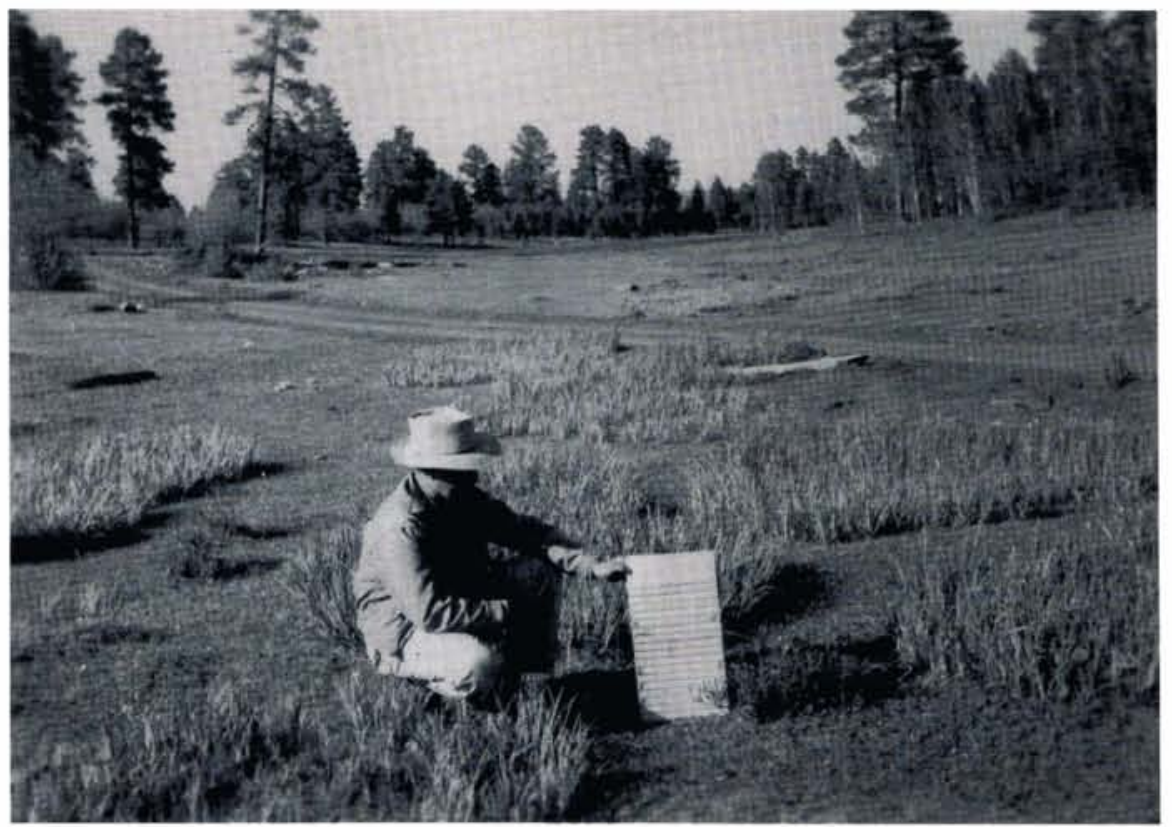

Photo by Arthur Cramer, 6-13-1950 - Denver Public Library, Western History Collection

Allotment was grazed season-long by 1,443 cow/calf pairs from May 16 to October 15 . Cramer noted 1-2" stubble on Kentucky bluegrass with use estimated at $70-80 \%$ by June 13 . He stated the grazing was much too early and use was too close. Precipitation for the year was $84 \%$ of "normal."

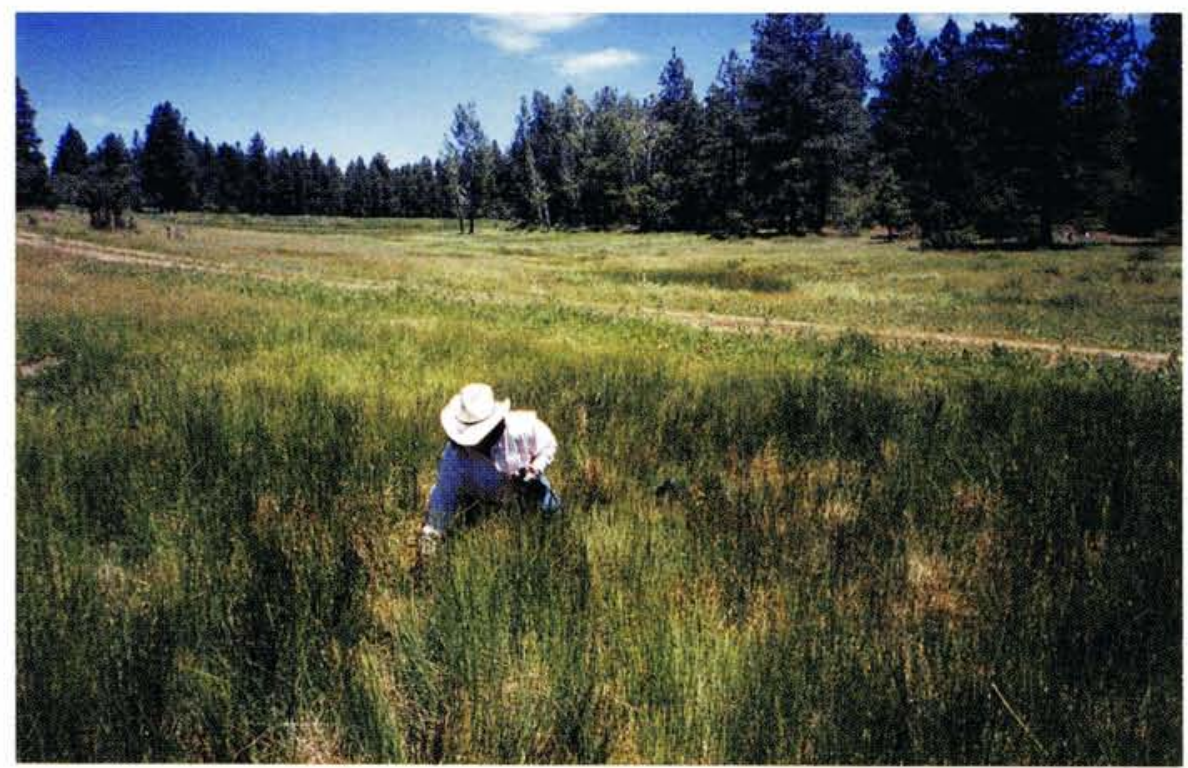

U.S. Forest Service

Original allotment was broken up into 4 allotmentments, grazed by 1,500 cow/calf pairs. This area is now part of the Horsefly allotment and grazed with 107 cow/calf pairs, 6/6-10/15. Allotment now managed under a deferred rotation system. Precipitation for the year was $88 \%$ of "normal." 


\begin{tabular}{|l|c|c|c|c|}
\hline \multicolumn{5}{|c|}{ The Human Population* } \\
\hline Year & World & United States & Colorado & Delta County \\
\hline $\mathbf{1 9 5 0}$ & $2,556,000,053$ & $151,325,089$ & $1,325,089$ & 17,365 \\
\hline $\mathbf{1 9 6 0}$ & $3,039,451,023$ & $179,323,175$ & $1,753,947$ & 15,602 \\
\hline $\mathbf{1 9 7 0}$ & $3,706,618,163$ & $203,302,031$ & $2,224,610$ & 15,316 \\
\hline 1980 & $4,453,831,714$ & $226,542,199$ & $2,209,036$ & 21,470 \\
\hline $\mathbf{1 9 9 0}$ & $5,278,631,759$ & $248,709,873$ & $3,303,377$ & 21,036 \\
\hline 2000 & $6,082,966,421$ & $281,421,906$ & $4,320,191$ & 27,034 \\
\hline
\end{tabular}

*Figures from U.S. Census Bureau

These figures indicate significant and dramatic changes in the human population for our world, the United States, Colorado and Delta County. Since 1950 the world population has increased 137\%, the United States population has increased $85 \%$, the population in Colorado has increased $226 \%$ and the population in Delta County has increased $56 \%$.

Since 1970 the world population has increased 64\%, the United States population has increased 38\%, the population in Colorado has increased $94 \%$ and the population in Delta County has increased $77 \%$.

These increases have put increased pressures on the natural resources on the planet, the United States, Colorado and Delta County. There are more houses and buildings, more roads, cars and traffic. We are all using more energy, more water and require more food. In addition we have more time and we are spending more of that time recreating on public land. These increases translate to more conflicts between all users on public lands.

on all lands in these areas. These pressures include increased demand for food, water, fiber, housing, energy, recreation, etc., and the numbers of people using public lands has increased dramatically.

\section{So, Has Range Management Failed?}

We posed the question in the introduction - has the science, efforts and funding of the last 50 years been mistaken, misdirected and misspent? No-we do not believe so. We believe that the science and profession of range management has solved many of the problems on America's rangelands.

Looking at the question from the perspective of the issues that Voigt raised in his book we no longer have too early, too heavy and too long grazing use. Comparing sites that were identified as damaged, depleted or unsatisfactory in the 1950's, range management has succeeded without question. This has occurred in spite of significant increases in both big game and human populations in the West.

Yet the question "Are America's rangelands healthy?" is continuously being raised. While this is a simple question, it is a difficult one to answer simply. This difficulty lies in the complexities of ecological processes, plant physiology and the in- herent variation of natural landscapes. The question should public lands be grazed by livestock is usually raised in a simplistic and rhetorical manner. As a profession we generally fail to respond in a similar fashion.

Is the land healthy? This will probably always be a contentious issue-we have difficulty defining what the potential of the land is, what it would be without human influence, and what it looked like before American settlement. With the increasing passage of time and the increasing changes we continue to make to the land this creates great difficulty in assessing what is human caused or influenced and what is "natural." In our view it is probably more appropriate to evaluate the land from the perspective of functionality - is the land functioning as a healthy landscape?

Undoubtedly, this review and these photographs will not convince all those who oppose livestock grazing on public lands. For many of these individuals their opposition is philosophical, emotional and complete. We have found that debating the merits of grazing domestic livestock with individuals who have a rigid anti-grazing paradigm to be unproductive. However, there are many individuals who are opposed to domestic livestock grazing on public 
lands due to a lack of knowledge or the misinformation that is being spread so aggressively by antigrazing zealots. We have found that providing factual and accurate information on grazing livestock on public lands can affect the understanding and attitudes of open-minded but uninformed or misinformed people. The answer to reaching these people is education.

As mentioned in the introduction nearly 50 laws were passed in the 1970's that relate to management of the national forests. However Congress did not ignore the national forests before or after the 1970's - today there are nearly 200 federal laws that affect the management of those lands. This has created a complex and sometimes conflicting array of mandates. This is not necessarily efficient, economic or even effective. The public land agencies will continue to manage the public lands as best as they can, though in all likelihood this will continue to be inefficient, costly and at times ineffective.

Management of the public lands is increasingly focused on process and not on the actual conditions on the land. This focus on process has created what the Chief of the Forest Service and others call "analysis paralysis." Possibly this may be the price of managing public lands in a democratic society. However, we believe that our best chance for successfully managing the public rangelands lies in management based on actual and factual on the ground conditions. Not on speculation and process.

There has been a dramatic improvement in range conditions over the past 50 years and America's public rangelands are generally healthy and functional. This improvement should be attributed to the efforts of the range managers and range scientists of the past 50 years.

Can America's public rangelands still be improved - absolutely! The science and profession of range management will continue to evolve - as it should. A profession that does not continue to grow will become stagnant, moribund and irrelevant. But in the course of change the profession should not lose sight of its basic reasons for existing. The following are two of the objectives of SRM-to properly take care of the basic rangeland resources of soil, plants and water and to improve the effectiveness of range management or obtain from range resources the products and values necessary for man's welfare. We believe these objectives correlate to Gifford Pinchot's description of the purpose of the national forests in 1907, "the land should be managed for the greatest good of the people in the long run." Let us continue our efforts keeping in mind this goal and these objectives.

About the Authors: Bradford is Rangeland Management Specialist on the Paonia Ranger District, GMUG NF, with over 20 years with the Forest Service; McConkey is Rangeland Management Specialist on the Paonia Ranger District, GMUG NF with 3 years with the Forest Service; Reed is Range Staff Officer for the GMUG NF with over 30 years with the Forest Service.

\section{References}

Gill, R. Bruce, 2001. Declining Mule Deer Populations in Colorado: Reasons and Responses. Special Report Number 77, Colorado Division of Wildlife, June 2001.

Pinchot, Gifford, 1907. The Use of the National Forests. USDA Forest Service.

Voigt, William J., 1976. Public Grazing Lands: Use and Misuse by Industry and Government. New Brunswick, New Jersey, Rutgers University Press.

Box, Thad, 2001. Listening to the Land: Ministers to the Land. Rangelands: Volume 23, No.6 December 2001.

Grand Mesa-Uncompahgre National Forest, Range and Wildlife Habitat Situation Assessment, 1975.

Gunnison National Forest, Livestock, Range and Wildlife Habitat Situation Assessment, 1975.

USDA Forest Service, Grazing Statistical Summary, FY 1980 USDA Forest Service, Grazing Statistical Summary, FY 1992 USDA Forest Service, Grazing Statistical Summary, FY 2001 